\title{
EGYPTIAN MYTH AND WHITMAN'S "LILACS"
}

\author{
ROSEMARY L. GATES
}

SEVERAL RECENT STUDIEs have called attention to the influence of Egyptology on the American Renaissance, and on Whitman's poetry in particular. ${ }^{1}$ In a discussion of "Song of Myself," Stephen Tapscott contends that Whitman "seems to have borrowed concepts, images, and a linguistic structure from his knowledge of Egyptian traditions." Among the Egyptian elements in Whitman's poetry, Tapscott identifies the Osiris figure as enabling the expansion of self to include all men in all times and places, and the hieroglyphic as allowing natural objects to point beyond themselves to metaphysical meanings. But little has been said of the Egyptian elements in one of Whitman's greatest poems, "When Lilacs Last in the Dooryard Bloom'd," other than Richard Chase's allusion to the poem's Egyptian atmosphere and Gay Wilson Allen's comment that "the funeral of the President seems to Whitman comparable in historical and tragic significance to the burial of one of those pharaohs of old whose hieroglyphic-decorated tombs ... he had seen so many times in the Egyptian Museum."3

Tapscott notes the similarity between Lincoln and the description of Rameses II (Sesostris) in a poem collected in Bucke's Notes and Fragments. ${ }^{4}$ Both Rameses and Lincoln were credited with emancipating slaves, and thereby inaugurating new ages of freedom. Both were tall, supple, bearded, wholesome, and wise. Both admired and respected the strength and courage of their enemies, and both respected all religions. Perhaps most significantly, both were assassinated after bringing peace to their nations. In his essay, "The Egyptian Museum," written in 1855, Whitman calls Rameses the greatest Egyptian, second only to Osiris. ${ }^{5}$ Whitman also would have known of the identification of all pharaohs with Osiris: in the earliest records of Egyptian theology, all pharaohs were said to become Osiris when they died. (The idea that all men, regardless of social status, became Osiris was a later development.) Osiris was a god of the afterworld, but Whitman was well aware that he was also the god of regenerating life, the god of agriculture responsible for the growth of crops who was the Egyptian counterpart to the Mediterranean gods that were the basis of the pastoral elegy tradition. ${ }^{6}$

It was the account of Osiris's death and the symbols associated with the story that formed the ritual and symbol of the Egyptian funeral. Richard Chase states that Whitman's best poems have a "mediating body of mythic narrative and metaphor." For "Lilacs," an important part of that mediating body of myth is Egyptian. An examination of the poem in light of the Egyptian material Whitman knew helps to elucidate some of the elements critics 
have found difficult to explain. ${ }^{8}$ Since the story is unfamiliar to most readers, I will give a brief account of it as found in Whitman's Egyptian sources, principally Sir John Gardner Wilkinson. ${ }^{9}$

Osiris was slain by his jealous brother Typhon following a successful mission that brought peace to Egypt by teaching agricultural skills. Typon tricked Osiris into lying down in a coffin he had made of cedar, slammed the lid shut, and launched itfrom the swampy waters near the Nile into the Mediterranean. After a long journey, the coffin came to rest on the shores of Syria, where a fragrant myrrh tree grew around it, enclosing the coffin. The king of Syria had the tree cut down and made into a pillar for the palace.

Meanwhile, Isis, sister and wife of Osiris, searched all over Egypt for her husband's coffin, weeping and mourning. She heard about the pillar, traveled to Syria, and became nursemaid to the king's son, whose nursery contained the pillar. Every night, Isis would turn herself into a swallow and fly around the pillar, singing mournfully. When she was discovered by the queen one night, she revealed herself as a goddess, and had the pillar cut open to remove the coffin. The pillar, which had been the grave of the god for many years, was anointed and made a shrine. The coffin was put on a boat and carried home to Egypt by the aid of the winds, which Isis commanded with her perfumed breath. She hid the coffin in the delta swamp where the Nile meets the ocean until she could arrange for proper burial. (Preparation for burial took several months.) There in the swamp, the body was dismembered by Typhon and scattered by the winds to all parts of Egypt.

The scattering of the body over the land symbolized in ritual the fertilizing of the land each year with the dead body of the god. Images of the god made of clay and vegetable mold mixed with grain seeds were buried in the fields following the harvest. The sprouting seeds were thought to ensure fertility for the whole field during the next growing season.

The soul-or divine essence-of all the wheat in a harvested field was thought to be subsumed into those seeds which were planted in the clay-mold image of the god. In a similar manner, men's souls were thought to be absorbed by Osiris. The funeral rites were a recapitulation of his death and burial. The dead man was given the title "Osiris" and was thereafter known by that appellation. What was celebrated in the funeral rites was not the accomplishments of the dead man, but that part of the man which was of the divine essence. If he had aspects of Osiris-goodness, truth, and justice-he was accorded a proper burial, a requirement for the peace of his soul and the peace of mind of his survivors.

Isis and Osiris cannot be located in any single element, such as the sea, the earth, the sun, or the stars. Rather, each represents a principle, along with a secondary derivative set of principles, that may occur in any or all of these natural elements. Osiris is the generative principle, so the aspects associated with him are those conducive to life-love, light, growth, order, and stability. Isis, as his counterpart, represents the matter upon which the 
generative principle acts. Associated with the fertile earth, she clings to love, light, and order - that is, with the orderly passage of the seasons and the growth of the crops. It is important to notice that Isis is not the earth itself; her principle, rather, is evident in the earth when it is fertile. Similarly, Osiris is not represented only by daylight. His principle of light and stability may be realized also on a calm and starry night. Likewise, a cloudy day or a stormy upheaval means that the opposing destructive principle, represented by Typhon, is ascendant. Typhon's aspects are chaos, disorder, darkness, decay, and death. The Egyptians believed that there was not absolute good or evil in the universe. Instead, there was a fluctuation of opposing principles. Like hieroglyphs, Whitman's images point toward a metaphysical idea and participate in a complex system of principles related to the Egyptian beliefs about the interaction of good and evil, life and death, joy and mourning.

Death, like Typhon's power, is celebrated in the Egyptian funeral ritual as a temporary but necessary part of the sacred realm. What is retrieved from the world by death will be given back as life: the process is imaged for Whitman in the sea. For Whitman, creating his own pantheon of symbols, the sea becomes a mother who in death welcomes her children back home:

Dark mother always gliding near with soft feet, . . .

Approach strong deliveress,

When it is so, when thou hast taken them

I joyously sing the dead,

Lost in the loving floating ocean of thee,

Laved in the flood of thy bliss $O$ death. . . .

The ocean shore and the husky whispering wave whose voice I know,

And the soul turning to thee $O$ vast and wellveil'd death,

And the body nestling close to thee. (11. 142-158) ${ }^{10}$

The Mother-Sea-Death is imaged as a loving protectress, enfolding the dead one. In Egyptian funerary symbolism, the goddesses Isis and Nepte were pictured both inside and outside of every coffin in kneeling postures in such a way that their open arms received the head and feet of the corpse. ${ }^{11}$ The two goddesses were called protectresses of the dead and receivers of the soul. Isis, as Nature, represented love and protection, as well as life and rebirth.

It is this kind of transformation of the Egyptian mythic material - of detail incorporated into Whitman's own vision - that is present in "Lilacs." Gay Wilson Allen has remarked that the image of the sprouting wheat spear in section five appears to be taken from fertility symbolism, though he does not identify it. ${ }^{12}$ The image recalls the funerary symbol of Osiris wrapped in a shroud with wheat spears growing from his corpse. The symbol was used universally on Egyptian tombs and represented to the Egyptians the same 
thing that Whitman's leaf of grass represented: the fluctuating principle of the universe evident as new life emerging from dead material. Osiris was the god of agriculture, specifically of wheat. Significantly, the wheat spear symbol is stronger in "Lilacs" than Whitman's familiar leaf of grass. ${ }^{13}$ The grass is present and growing, but the metaphor is not fully drawn. The significance of the catalogue of new growing things is encapsulated in the image of the wheat spear emerging from its shroud, "uprisen" or resurrected from a dead kernel of wheat. The passage shows life continuing despite death. Life surrounds the passage of the coffin:

Over the breast of the spring, the land, amid cities,

Amid lanes and through old woods, where lately the violets peep'd from the ground, spotting the grey debris,

Amid the grass in the fields each side of the lanes, passing the endless grass,

Passing the yellow-spear'd wheat, every grain from its shroud in the dark-brown fields uprisen,

Passing the apple-tree blows of white and pink in the orchards,

Carrying a corpse to where it shall rest in the grave,

Night and day journeys a coffin. (11. 26-32)

This proclamation that life goes on in the face of death, and is in fact replenished, is the equivalent of the Egyptian celebration of Osiris's resurrection in the form of new wheat. The description of the vegetation runs counter to the pastoral elegy tradition, which shows life stopping, wilting in mourning for the dead god. Death does not bring more death; it brings more life. The destructive principle is replaced by the regenerative power. The coffin passes, and we are shown freshness, life, and the orderly process of nature.

This idea of the regenerative principle ascending after the temporary ascendance of the destructive principle is extended and strengthened in sections eleven and twelve. Whitman's description of the tomb differs from the frozen, stone-cold, dark atmosphere of the sea-tomb in "Lycidas" and the stone tomb in "Adonais." Whitman's passages depict scenes teeming with light and life. The tomb is perfumed and decorated with pictures of the everyday life of the people. It is Egyptian, as Allen noticed, and signifies a historical and tragic relation of Lincoln's death to that of the pharaohs.

The dominant image in the two tomb sections is the sun-the image which decorated every Egyptian tomb. The sun was a central image in Egyptian funeral symbolism, where the eye of Osiris is represented as the sun and symbolizes the resurrection and salvation of both the dead man and the land in the risen Osiris. The sun was also a symbol of the Demiurgos, the most visible evidence of the fire-spirit that was thought to be the divine essence in all things. The sun does not represent Osiris per se, but rather the immortality of Osiris, who made immortality possible and who was symbolically cradled in the arms of the sun. For Osiris to be cradled in the sun's arms represented the resurrection of the god, the embrace by life, of the god and all 
that he represented (a dead man in a particular funeral or the land in the spring). ${ }^{14}$ In section eleven the sun is shown suffusing the land, sea, and sky with a bright, divine ("measureless") light:

Pictures of growing spring and farms and homes,

With the Fourth-month eve at sun-down, and the gray smoke lucid and bright,

With floods of the yellow gold of the gorgeous, indolent, sinking sun, burning, expanding the air,

With the fresh sweet herbage under foot, and the pale green leaves of the trees prolific,

In the distance the flowing glaze, the breast of the river, with a wind-dapple here and there,

With ranging hills on the banks, with many a line against the sky, and shadows,

And the city at hand with dwellings so dense, and stacks of chimneys,

And all the scenes of life and the workshops, and the workmen homeward returning. (11. 81-88)

The lush new growth is expressed by the words "growing," "prolific," "fresh sweet herbage," and "pale green leaves" (the color of newly forming foliage). The piling up of details of vegetable and human life and activity gives a feeling of denseness. The light of the sun spreads over all this teeming life, making the smoke "lucid and bright," "burning, expanding the air," transforming the scenes in the distance into a melted, "flowing glaze." The sun is there, but it is at the low point of its strength, near the evening, and there is a suggestion of things merging into a state of undifferentiation. The picture describes the eve of Lincoln's death. The destructive principle reigns. The sun is "sinking" and "indolent," and there are shadows cast upon the land.

The second tomb passage describes the vision of post-war America. It is the time of fulfillment and prophecy, the "fulfill'd noon" when the sun is at its zenith:

Lo, body and soul-this land,

My own Manhattan with spires, and the sparkling and hurrying tides, and the ships,

The varied and ample land, the South and North in the light,

Ohio's shores and flashing Missouri,

And ever the far-spreading prairies cover'd with grass and corn.

Lo, the most excellent sun so calm and haughty,

The violet and purple morn with just-felt breezes,

The gentle soft-born measureless light,

The miracle spreading bathing all, the fulfill'd noon,

The coming eve delicious, the welcome night and the stars,

Over my cities shining all, enveloping man and land. (11. 89-98) 
The sun in this passage is personified as a god or great ruler, "most excellent," "calm and haughty." Its light is a "miracle spreading bathing all." The passage shows America healed, North and South together, by the miraculous light. Light is "sparkling" off the tides and ships, off the land, and off the prairies now lush with the grass and corn that was only sprouting in sections five and eleven. The light, however, continues after sundown as the stars illuminate the land. Clearly the sun is the strongest manifestation of the orderly reign of the principle of light and growth, but the stars are another indication that the cloud is gone. The haziness of the fourth-month eve is gone. The darkness in section six and the cloud that is present through most of the poem are at this moment in the future gone.

The sun cannot be equated with Lincoln nor with Osiris. It only reveals in the relative strength at any time which stage of fluctuation is being experienced. Similarly, the star cannot be too closely associated with one thing. Sometimes it seems to represent Lincoln (section two) and other times a guardian friend (section eight). Both sun and star are manifestations of the light principle, which the Egyptians associated with Osiris. Death is associated with the disappearance of the star behind a cloud and with the loss of power by the sun at sundown. Death is a moment in the fluctuation of the universe when the dark principle associated with Typhon ascends. The murkiness of the cloud and the haze and shadows of sundown reflect the chaotic undifferentiation of Typhon. The ebb and flow of the two principles is the necessary operation of the universe, since new life proceeds from the old, dead matter. From the shrouded wheat spear grows a new spear, from the dark mother death new births occur.

Another element of the poem that suggests Egyptian influence is the perfumed atmosphere, which pervades the poem but is especially strong in the final reconciliation scene. There the speaker is partially readied for his revelatory vision by the bird's song, but the perfume contributes to his experience as well. Immediately before his soul tallies with the bird's song, he notices the perfume:

From deep secluded recesses,

From the fragrant cedars and the ghostly pines so still,

Came the carol of the bird. (11. 129-131)

The perfume mingles with the bird's song at the moment the speaker's eyes are opened to the transcendent vision:

Loud and strong kept up the gray-brown bird,

With pure deliberate notes spreading filling the night.

Loud in the pines and cedars dim,

Clear in the freshness moist and the swamp-perfume,

And I with my comrades there in the night.

While my sight that was bound in my eyes unclosed. . . (11. 164-169) 
Finally, the poem itself ends with the reconciliatory experience symbolized in the trinity of lilac, star, and bird immersed in the perfume of the swamp:

Lilac and star and bird twined with the chant of my soul,

There in the fragrant pines and the cedars dusk and dim. (11. 205-206)

The fragrance of the evergreens is so important Whitman places it at the end with the trinity where it has a pivotal function in the reconciliation experience. It acts as an emollient to soothe the soul, to dispel its cares (it replaces the lilac fragrance associated with the thought of Lincoln), and make it ready for spiritual understanding. The Egyptians used perfume this way in their rituals in the belief that perfumes in the air dissipate anxieties, brighten the imaginative faculties, and cure emotional and irrational disequilibrium in the soul. ${ }^{15}$ The cedar and the pine, both sacred to Osiris, are the central fragrances in this section. The cedar was especially important in funeral ritual: its oil was the chief ingredient used to preserve the body and its wood was chosen by those who could afford it for the coffin. Both practices derived from the myth that Osiris was enclosed in a cedar coffin. The fragrance of the Egyptian funeral is transferred to the live trees of Whitman's swamp, where it functions for his speaker as it functioned for the Egyptians. Though Chase says that the "Egyptian atmosphere of odors, perfumes, herbage, pine and cedar" is a "substitute" of "antiseptics for the healing process of nature,"16 it is rather in the essence of nature-in the natural fragrance of the pine and cedar trees and in the song of "Nature pure and holy" that Whitman viewed the thrush as singing ${ }^{17}$ - that the speaker finds healing.

These and other elements in "Lilacs" reveal that Whitman borrowed from Egyptian sources. Of the several emblems and practices Wilkinson describes as present in every Egyptian funeral, most appear in Whitman's elegy, often with only slight transformation. ${ }^{18}$ The bird as emblem of and messenger to the soul (1:367), the sun as symbol of resurrection of man and land in Osiris, the anointing of the tomb with perfumed breath, and the presence of fragrance to soothe the emotions and make the soul ready for peace were all features of every Egyptian funeral. The thyrsus, a stalk of flowers bound with leaves of a shape that resembled the heart, where Osiris has his home, was carried in funeral processions (1:284). Offerings of flowers on the bier were made, not in tribute to the dead man, but in tribute to the gods and goddesses associated with death $(1: 19,259,270 ; 2: 367)$. Whitman gives roses, the characteristic tribute flower, to death, which becomes a goddess in section fourteen. The carol in that section is similar in style and wording to the processional chants, and praises, like them, both life and death $(1: 98,140 ; 2: 367)$-not the afterlife as is characteristic of Christian dirges and the pastoral elegy tradition. And finally, Egyptian mourners were carried forward in the funeral procession by divine inspiration (1:285); similarly, the mourner in "Lilacs" is unable to move toward reconciliation until he is seized 
by divine messengers and taken to the swamp to receive visionary inspiration through nature's messenger, the bird.

One other important element of the poem-its dramatic structure-may owe some influence to the Isis/Osiris myth. The remembrance of the journeys of Osiris's coffin and Isis's lamentation and search for her lost beloved formed the basis of the Egyptian funeral ritual. The dramatic structure of "Lilacs" shares with this myth the pattern of two intertwining journeys: one of a coffin containing the corpse of an assassinated hero, and the other of the wandering mourner, searching for him and grieving for his death. Whitman had in fact used the Osirian coffin in his early poem "Pictures."19

The dead hero in "Lilacs," like the dead Osiris, appears only as a corpse in a coffin. The coffin makes its way through the land and a "sea of faces" $(1: 38)$. In sections five and six we have our only encounters with the physical man, and it is a corpse in a coffin:

Carrying a corpse to where it shall rest in the grave, Night and day journeys a coffin.

Coffin that passes through lanes and streets,

...

$\ldots$ the arriving coffin ...

$\ldots$

Here, coffin that slowly passes,

I give you my sprig of lilac. (11. 31-45)

Significantly, Whitman does not address this corpse but the coffin. Coffin, not corpse, is the emblem of death. The decking of the coffin in section seven becomes a tribute for all coffins, symbolically for all death. This death, this corpse, this coffin is not singular; it is representative. Whitman, in following after the Egyptian type of funeral, celebrates the principles of life and death. Reference to the individual is only in those repects that he shows qualities of the divine spirit. Aside from the coffin, the only other references to Lincoln are as the western star and as a wise and sweet soul.

The journey of the coffin has been attributed to an actual event because the description in sections five and six is similar to the actual journey taken by Lincoln's coffin. The springtime countryside, the mournful faces, the black-draped cities, the mournfully singing people, the light shining in the night have all been shown to be part of historical event. ${ }^{20}$ Yet, other facts that might have been included were omitted. The train, for instance, is missing, though it would seem to be an important detail. Facts about the death are absent. There is no display of the body. The stopping points along the journey are not named. Instead, the coffin is emphasized. The coffin makes the journey as if floating through the countryside and cities. The lengthy sentence which comprises section five ends in a short independent clause, further focusing our attention on the coffin and the continuousness of its journey: 
"Night and day journeys a coffin." The focus is immediately continued in the opening of section six: "Coffin that passes through lanes and streets...." In this section we watch the coffin passing amid grieving people. All the trappings of funeral ritual are there. The details are historically accurate and American, but they are also the elements of Egyptian funeral processions: the lighted torches, the dirges, the black-clothed figures, the instrumental music, the placing of a heart-shaped plant on the coffin, the depot (a river port in the Egyptian context ${ }^{21}$.

In the second journey of the poem, which parallels Isis's wandering, mournful search for Osiris's body, the speaker moves about erratically and sorrowfully. Like Isis, the speaker is a seer, loves the dead hero, mourns him, and ends the journey in a swamp. Both the speaker and Isis have perfumed breath which mixes with the wind. Both of them perfume the tomb of the dead subject, not the body, as is the practice of Greek, Roman, and Christian ritual. Both must rely on the form of the bird to be able to sing. Isis changed herself into a swallow to sing her mournful song around the pillar concealing Osiris; the speaker in "Lilacs" is unable to sing except through the bird's carol.

Though it is impossible to determine the extent to which Whitman consciously used Egyptian myth and symbol in composing the poem, the many parallels between the Egyptian materials Whitman knew and the elements of the poem suggest direct influence. Egyptology was, for Whitman, as Tapscott has well documented, a deep interest that influenced his art in many ways. The Osiris myth with its obvious analogues to Lincoln, its inherent symbolism of regeneration, and its significance of the dead subject providing new life for the nation supplied Whitman with a mediating body of myth well suited to the situation of Lincoln's death in war-torn America and to Whitman's own mournful state at the death of his beloved President.

\section{The Catholic University of America}

\section{NOTES}

1 For broad influence, see John T. Irwin, Egyptian Hieroglyphics: The Symbol of the Egyptian Hieroglyphics in the American Renaissance (New Haven: Yale University Press, 1980). Two other books have sections devoted to the influence of myth on Whitman, with some discussion of Egyptian myth: Robert D. Richardson, Jr., Myth and Literature in the American Renaissance (Bloomington, Indiana: Indiana University Press, 1978); and Lewis Hyde, The Gift: Imagination and the Erotic Life of Property (New York: Random House, 1979; rpt. 1983). The first connection of Whitman to Osiris was made by Esther Shepard, "Possible Sources of Some of Whitman's Ideas and Symbols in Hermes Mercurius Trismegistus and Other Works," MLQ 14 (1953), 61-81. The most complete account of Whitman's Egyptian poetry is Stephen J. Tapscott's essay, "Leaves of Myself: Whitman's Egypt in 'Song of Myself," American Literature, 50 (March 1978), 49-73.

2 Tapscott, 58. 
3 Richard Chase, Walt Whitman Reconsidered (New York: William Sloane Associates, 1955), 145; and Gay Wilson Allen, The Solitary Singer (New York: Macmillan, 1955), 357.

4 Tapscott, 72. The poem to which Tapscott refers is found transcribed in two places: Richard Maurice Bucke, ed., Notes and Fragments (1899; rpt. Folcroft Library Editions, 1972), 15-16; and Walt Whitman, Leaves of Grass: Authoritative Texts, Prefaces, Whitman on His Art Criticism, ed. Sculley Bradley and Harold W. Blodgett (New York: W. W. Norton, 1973), 687.

5 Walt Whitman, “The Egyptian Museum," in New York Dissected, ed. Emory Holloway and Ralph Adimari (1936; rpt. Folcroft Library Editions, 1972), 31-40.

6 Whitman knew of the fertility-vegetation myth, and knew that all of the Mediterranean vegetation-gods-Daphnis, Dionysus, Adonis, Bacchus, Attis, Tammuz, and Osiris-were essentially the same. He also knew of the ritual ceremonies surrounding these figures. Notes he made on these gods and their rituals are preserved in the Feinberg Collection, Container 39, Library of Congress, Washington, D.C. And, of course, the rituals surrounding Osiris were described at length in John Gardner Wilkinson's books.

Also, Whitman would have seen many pictures of Osiris's corpse wrapped in a shroud with wheat spears growing from it in the Egyptian Museum, which he frequented in the early 1850s. For a catalogue, with pictures, of the Museum's holdings, see Carolyn Ransom Williams, Catalogue of Egyptian Antiquities (New York: New York Historical Society, 1924). For a description of the collection as it existed during Whitman's time, see "Dr. Abbott's Egyptian Museum, described," New York Times 24 Mar. 1860: 3F.

7 Richard Chase, "Whitman's Verbal Structures," in Whitman the Poet: Materials for Study, ed. John C. Broderick (Belmont, Calif.: Wadsworth Publishing Company, 1962), 116.

8 The poem, of course, belongs to several traditions, for it includes elements of pastoral elegy, history, Christianity, and Greek and Roman myth. The influences of these traditions on "Lilacs" have been explored: see especially Richard P. Adams, "Whitman's 'Lilacs' and the Tradition of Pastoral Elegy," PMLA, 72 (1957), 479-487; Harsharan Singh Ahluwalla, "The Private and Public Self in Whitman's 'Lilacs," Walt Whitman Review, 23 (December 1977), 166-175; Richard Allen Davison, “Ambivalent Imagery in Walt Whitman's 'Lilacs,'” Walt Whitman Review, 14 (June 1968), 54-56; Charles Clay Doyle, "Poetry and Pastoral: A Dimension of Whitman's 'Lilacs," Walt Whitman Review, 15 (December 1969), 242-245; Edwin Haviland Miller, Walt Whitman's Poetry: A Psychological fourney (New York: New York University Press, 1968); Donald D. Kummings, "Whitman's Voice in 'Song of Myself': From Public to Private," Walt Whitman Review, 17 (March 1971), 10-15; and Howard Waskow, Whitman: Explorations in Form (Chicago: University of Chicago Press, 1966). Some elements that have not been explained fully by these other traditions can be explained from the Egyptian material, as my essay shows.

9 In a note Holloway and Adimari appended to the Egyptian essay (Walt Whitman, "The Egyptian Museum," reprinted from Life Illustrated, December 8, 1855 in New York Dissected), Whitman recommended Sir John Gardner Wilkinson's two volume work, A Popular Account of the Ancient Egyptians (New York: 1854). Wilkinson had published three earlier volumes, The Manners and Customs of the Ancient Egyptians (London: John Murray, Albemarle Street, 1841). Factual details in the essay and in passages from "Song of Myself" and other early poems agree with Wilkinson. Whitman had also probably read Plutarch's "Isis and Osiris" segment of the Moralia, Vol. 5, trans. Frank Cole Babbitt (Cambridge, Mass.: Harvard University Press, 1936). Notes and Fragments contains several references to Plutarch (pp. 94, 99, 112, 113). I have used Wilkinson for the material on Isis and Osiris and Egyptian thought. Tapscott gives a more complete account of Whitman's readings on Egypt. Whitman would have known more about Egyptology than appears in any of his reading, since he spoke frequently with the owner of the Egyptian Museum, Dr. Henry Abbott, on his frequent visits there. 
The story of Isis and Osiris is dispersed intermittently throughout Wilkinson's rather poorly organized books. For the version of the story I relate, I have relied primarily upon the 1854 volumes, as it is certain Whitman had read these. Pages 120, 286, and 287 of the second volume contain the core of the story.

10 References to Whitman's poems are from the Norton Critical Edition of Leaves of Grass, ed. Sculley Bradley and Harold W. Blodgett (New York: W. W. Norton, 1973).

11 Wilkinson, Account, 2:396.

12 Allen, Reader's Guide, 200.

13 Lewis Hyde discusses the relation of Whitman's grass and wheat spear to ancient fertility myths, including Osiris, in The Gift, 179-182; Hyde discusses especially the Osirian myth in Whitman's poem, "This Compost." James E. Miller has mentioned the wheat spear in "Lilacs" as belonging to ancient fertility myth, though he does not identify it further; in "'Lilacs': Grief and Reconciliation," in A Critical Guide to Leaves of Grass (Chicago: University of Chicago Press, 1957), 117-119.

14 See especially Wilkinson, Account 1:257, 290; 2:53, 367, 386, 391; Plutarch, 153.

15 Fragrance was supposed to cleanse the air, which was constantly being breathed by unhealthy and diseased bodies. Also, it was supposed to counteract the heavy, depressing night air by stimulating the olfactory sense. See Plutarch, "Isis and Osiris," Moralia, 5:185-191; and Wilkinson, Account, 2:338-339.

16 Chase, Walt Whitman Reconsidered, 145.

17 In the notebook on birds, Feinberg Collection, Container 30, Library of Congress, Washington, D.C., compiled while he was writing "Lilacs," Whitman develops the bird as a kind of religious figure, secluded like a holy hermit, a spokesman for "holy" Nature, singing her hymns:

Hermit Thrush Solitary Thrush ... is very secluded ... - his song is a hymn-real seriously sweet-in earnest - the mockingbird is a wonderful intellectual music-in swamps-is very shy-is our best songster-song clear \& deliberate-has a solemn effect ... . it is rare-only those that frequent the deep and remote dark woods hear it - . . is the bird of the solemn woods \& of Nature pure and holy.

Whitman's use of such terms as "solemn," "hymn," and "holy" indicates the bird's religious function. The mockingbird's song is "intellectual," but the thrush's song is primal. The bird lives secluded from civilization, and knows nature in her purest, most primitive state, and, Whitman writes, her "holy" state.

In Egyptian lore Isis, goddess of nature and truth, often appeared as a bird in her role as muse to poets (Plutarch, 9-13). Whitman's bird in "Lilacs" and in his earlier poetry may owe something to the Egyptian material, though of course the uses of birds by English and American poets are more direct influences.

18 The references to Wilkinson's Popular Account are cited parenthetically by volume and page numbers in this paragraph.

19 "Pictures" is included in the Norton Critical Edition of Leaves of Grass, p. 646. The coffin is described in line 73. Earlier lines in the poem include Egyptian imagery: 11. 16, 64, 65.

20 Allen, The Solitary Singer, 354-359; Chase, Walt Whitman Reconsidered, 139-140.

21 Wilkinson refers repeatedly to river ports in Egypt as "depots." 